\title{
REVIEW
}

\section{Biological features of the clone involved in primary amyloidosis (AL)}

\author{
V Perfetti ${ }^{1}$, M Colli Vignarelli ${ }^{2}$, S Casarini $^{2}$, E Ascari ${ }^{1}$ and G Merlini ${ }^{2}$ \\ ${ }^{1}$ Internal Medicine and Medical Oncology, Department of Internal Medicine, and ${ }^{2}$ Biotechnology Research Laboratories, IRCCS Policlinico S \\ Matteo, Department of Biochemistry, University of Pavia, Pavia, Italy
}

\begin{abstract}
Primary light chain-associated amyloidosis $(\mathrm{AL})$ is a plasma cell dyscrasia that causes morbidity via systemic tissue deposition of monoclonal light chains in the form of fibrils (amyloid). It is the most common form of systemic amyloidosis in Western countries and is rapidly fatal. Knowledge of the pathobiology of the underlying B cell clone is of primary importance for the design and optimization of therapeutic strategies. Leukemia (2001) 15, 195-202.
\end{abstract}

Keywords: primary amyloidosis; AL amyloidosis; plasma cell dyscrasias; B cell lymphoproliferative disorders

\section{Amyloid: common elements}

Amyloid is an extracellular deposit mainly constituted of autologous proteins that produces a diagnostic apple-green birefringence when viewed in polarized light after Congo red staining, suggesting an organized structure. Electron microscope analysis revealed that amyloid is composed of rigid unbranched aggregated fibrils of indefinite length, 7.5 to 10 $\mathrm{nm}$ wide. ${ }^{1}$ Each fibril consists of units (filaments) that are mainly composed of proteins arranged in an antiparallel, cross -pleated sheet configuration with strands perpendicular to the long axis of the filament. Exactly how fibrils are formed from filaments is unknown. A recent model involves two filaments that intertwine to form a protofibril, and two protofibrils, or alternatively three filaments directly, that intertwine to form a fibril. $^{2}$ The peculiar structural architecture of amyloid is considered responsible for its typical staining properties. $^{3}$

Amyloid is found in a variety of hereditary and acquired pathological conditions. ${ }^{4}$ More often systemic, ${ }^{5}$ it can occasionally present as a single mass (amyloidoma) or confined to a specific organ, particularly the brain, upper and lower airways, lymph nodes, thyroid, Langherhan's islets or the gastrointestinal tract. Classification is based on the biochemical nature of the principal protein extracted from amyloid and approximately 20 unrelated amyloidogenic proteins are presently known. ${ }^{6,7}$ These are usually synthesized as soluble intact precursors of the $\mathrm{NH}$ 2-terminal fragments found in amyloid. However, cleavage is not essential for amyloidogenesis and it is unknown whether proteolysis occurs prior to, during, or after protein deposition. The most common forms of amyloidosis and their characteristics are reported in Table 1.

Amyloid fibrils are insoluble and relatively resistant to proteolytic degradation. However, amyloid deposition is not irreversible, it results from imbalance in production of the amyloid protein precursors and resorption. Clinical evidence

Correspondence: V Perfetti, Internal Medicine and Medical Oncology, Department of Internal Medicine, University Hospital, IRCCS Policlinico S Matteo, P le Golgi 2, 27100 Pavia, Italy; Fax: 390382 525222

Received 10 April 2000; accepted 5 September 2000 documents that amyloid deposits frequently regress when the supply of the fibril precursor is reduced, ${ }^{8}$ particularly in secondary AA amyloidosis, ${ }^{9,10}$ but also in AL. ${ }^{11}$

Amyloid deposition rate can be extremely variable, but it is believed that a long period of time is usually needed for amyloidosis to become clinically manifested. The precise mechanisms by which amyloid deposits damage organ function are as yet undetermined. Many of the pathological effects of amyloid can be attributed to its physical presence: amyloid accumulates in the blood vessels and in the extracellular space, hindering exchanges and producing space-occupying effects and altered tissue architecture. However, clinical observations suggest that damage does not depend only on the amount of amyloid deposited..$^{8,12}$ Indeed, the relationship between the quantity of amyloid and the resulting functional disturbance is poor ${ }^{11}$ and certainly other factors are involved. Many observations suggest that structured intermediates of amyloid fibrils may be responsible for the damaged organ function. Protofibrils, probably exposing several highly reactive sites, could bind tightly to any number of cellular targets, triggering, for example the apoptotic cascade. ${ }^{13}$

\section{AL amyloidosis}

Light-chain related $(\mathrm{AL})$ amyloidosis is the most common form of amyloidosis in Western countries and the only one caused by a tumor. Though occasionally localized and susceptible to surgical eradication, AL amyloidosis is usually systemic, incurable and leads to organ failure and eventual death. A marrow plasma cell (PC) clone synthesizes structurally abnormal monoclonal light chains that form amyloid. Typically, numbers of clonal PC are small, proliferative activity minimal, and monoclonal protein concentration very low with lambda isotype predominance; this condition is termed 'primary amyloidosis'. In some cases, light chain-amyloidosis can complicate multiple myeloma (MM) and, occasionally, Waldenström's macroglobulinemia or B cell lymphomas, and it is sometimes difficult to distinguish between $M M$ with light chain-amyloidosis and primary amyloidosis. ${ }^{14}$

Virtually any organ excluding the brain (but not brain vessels) can be targets of amyloid deposition, and in almost any combination. However, a single or a few organs dominate the clinical picture. Nephrotic syndrome and congestive heart failure (restrictive cardiomyopathy) are most frequently observed. Although AL is invariably fatal, prognosis varies widely according to the involvement of vital organs, and heart involvement is by far the most important adverse prognostic feature. ${ }^{15}$ The current therapeutic approach is multifaceted, aimed at controlling the underlying PC dyscrasia, ${ }^{8,16-19}$ at interfering with amyloid deposition, ${ }^{20}$ and at providing the best supportive therapy. ${ }^{8}$ Nevertheless, therapy is unsatisfactory with the median survival being between 2 to 3 years, ${ }^{21,22}$ 
Table 1 The most common forms of amyloidosis and their characteristics

\begin{tabular}{|c|c|c|}
\hline Type & Fibril precursor protein & Clinical features \\
\hline$A L$ & $\begin{array}{l}V \text { region fragments of } \\
\text { monoclonal light chains }\end{array}$ & $\begin{array}{l}\text { Small indolent bone marrow PC clone (primary) or associated with myeloma or } \\
\text { macroglobulinemia, (ratio of to }, 3: 1 \text { ) }\end{array}$ \\
\hline AA & SAA & $\begin{array}{l}\text { Reactive amyloidosis associated with hereditary (familial mediterranean fever) or } \\
\text { chronic inflammatory diseases, eg tubercolosis, rheumatoid arthritis, Castleman's } \\
\text { disease }\end{array}$ \\
\hline ATTR & Transthyretin & Familial (autosomal dominant mutations) or senile \\
\hline A & A PP & Alzheimer's disease \\
\hline $\mathrm{A}_{2} \mathrm{M}$ & 2-microglobulin & Dialysis associated \\
\hline
\end{tabular}

AL, immunoglobulin light chain amyloidosis; AA, amyloid A protein amyloidosis; ATTR, transthyretin amyloidosis; A , Alzheimer's amyloidosis; $\mathrm{A}_{2} \mathrm{M}, \quad$ 2-microglobulin amyloidosis; SAA, serum amyloid A protein; A PP, amyloid protein precursor; V, variable region; PC, plasma cell.

and only a small subset of patients (5\%) surviving for 10 years or more. $^{23}$

Since only a few Bence-Jones proteins form amyloid, research efforts have been directed mainly towards characterizing the structural and biochemical features of amyloidogenic light chains. ${ }^{24}$ Loss of variable $(\mathrm{V})$ region domain stability because of amino acid substitutions particularly in framework, ${ }^{25,26}$ but also in CDR regions, ${ }^{27}$ appears to play a key role in fibril formation. ${ }^{27,28}$ Much less attention has been focused on the study of the amyloid cell clone, though a better understanding of the tumor biology is of major importance for designing new therapeutic strategies.

\section{The cellular composition of the amyloidogenic clone}

The bone marrow is a major site of serum immunoglobulin (Ig) production, particularly IgG, and it is involved in T cell dependent antibody responses. ${ }^{29-32}$ Plasmablasts selected for the improved antigen binding of their surface immunoglobulins leave the germinal centers and find the appropriate surface interactions with adhesion molecules and cytokine feeding in the bone marrow microenvironment, where they transform into immunoblasts and then develop into PC. ${ }^{33}$ Marrow PC very seldom divide and probably live for long periods of time, ${ }^{34}$ and the bone marrow milieu satisfies the requirements for their survival. Amyloidogenic PC probably have similar requirements: though clonal PC can be present in tissues and be responsible for localized forms of $\mathrm{AL}$ amyloidosis, $^{35-37}$ amyloidogenic PC most frequently reside in the bone marrow while amyloid deposits are systemic, caused by local deposition of circulating light chains. Monoclonal antibodies that recognize specific antigenic determinants on the tumor Ig-variable regions (private idiotopes) are particularly useful for studying the composition and antigenic phenotype of B cell clones. To this end, monoclonal anti-idiotypic antibodies were raised in mice by repeated immunization with the patients' monoclonal components. ${ }^{38,39}$ These were used as probes to look for clonal cells in the patient's bone marrow and peripheral blood by immunofluorescence methods. ${ }^{39}$ Results of these studies provided an initial elucidation of the clonal composition, phenotype and behavior.

\section{The bone marrow amyloidogenic cells: lymphoid, lymphoplasmacytoid and plasma cells}

Three types of amyloidogenic cells were present in the bone marrow: (1) lymphoid cells, which were slightly larger than common peripheral blood lymphocytes (47\% CD45RA ${ }^{+}, 28 \%$

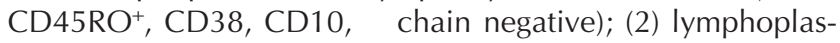
macytoid cells with more abundant cytoplasm (53\% CD38 ${ }^{+}$, CD45RA, CD45RO, CD10 negative); (3) PC that were very similar to normal PC in morphology and antigenic profile $\left(\mathrm{CD}_{38}{ }^{+}, \mathrm{PCA}^{+}\right.$, negative for CD56, CD10, CD20, CD45RA, CD45RO, HLA-DR). Plasma cells were mostly morphologically mature (high Ig content, large size, eccentric nuclei) and constituted a fraction (approximately $65-75 \%$ ) of the PC expressing the same isotype. Cell kinetic analysis of mature PC revealed a minor, but significant, replicative activity $(0.2-$ $0.4 \%$ of cells in S-phase) in these patients, whereas normal PC do not incorporate bromodeoxyuridine (PC labeling index). Lymphoid and lymphoplasmacytoid idiotype positive cells constituted a relevant fraction (approximately 40-50\%) of the amyloidogenic bone marrow clone. These results document that the amyloid clone infiltrates the bone marrow more extensively than estimated by simple morphological study.

The marrow PC labeling index was analyzed by the Mayo group $^{40}$ and failed to reveal proliferative activity in 76 of 103 (74\%) amyloid patients without associated MM; PC labeling index 0 was a negative prognostic factor (median survival, 14.1 months). Since not all monotypic PC are clonal, but resting normal PC are present (labeling index $=0$ ), ${ }^{39}$ PC labeling index may be underestimated in $\mathrm{AL}$.

The bone marrow PC percentage and intracytoplasmic light chain isotype ratio present a high degree of variability in $\mathrm{AL}$ amyloidosis. Infiltration is frequently minimal resembling normal bone marrow, and alteration of / ratio by immunofluorescence is of diagnostic ${ }^{41,42}$ and prognostic value. ${ }^{43}$ Sixty percent of patients have $10 \%$ of marrow $\mathrm{PC}^{15,44}$ and median PC infiltration is about $7-8 \% .{ }^{21,43}$ Therefore, a 'normal' bone marrow PC count should not be used to exclude the diagnosis of $\mathrm{AL}$. The degree of marrow infiltration negatively influences survival. ${ }^{43,44}$

\section{The circulating amyloidogenic cells}

Idiotypic monoclonal antibodies revealed a population of small lymphocytes (Figure 1) which constituted a minority (5$10 \%$ ) of the total circulating B cells. By double-color immunofluorescence, Id+ cells expressed B cell associated antigens (CD19, CD20, CD22, CD45RA, HLA-DR) and surface Ig with the same isotype as the monoclonal component (postswitched B cells). Plasmacytoid (PCA1, CD38), T (CD3, CD5), monocytic (CD14), activation (CD10, CD25, CD38, CD71) and progenitor (CD34) markers were negative. These cells 


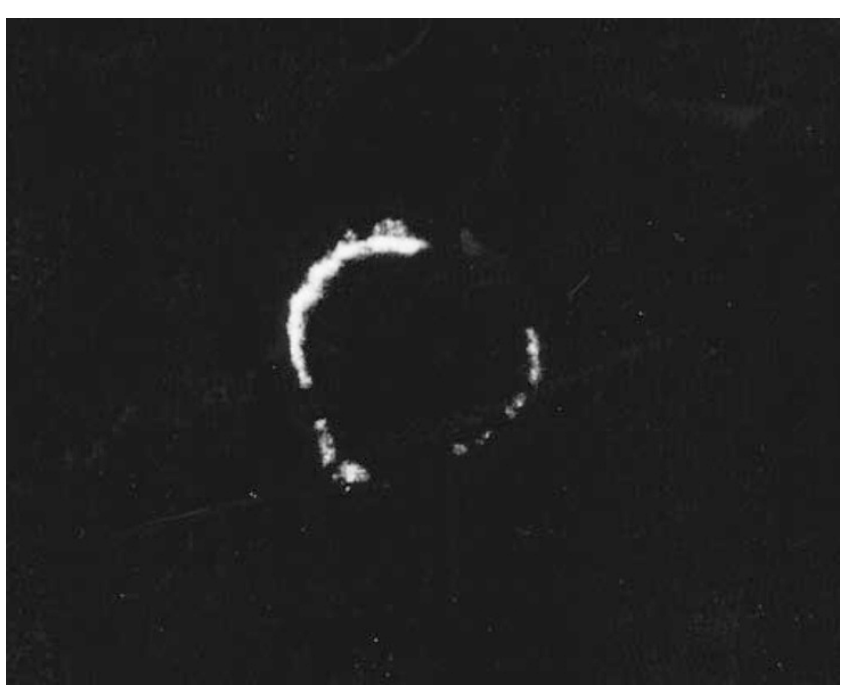

Figure 1 Circulating clonal lymphocytes in AL amyloidosis. Membrane monoclonal immunoglobulins as revealed by indirect surface fluorescence using anti-idiotypic antibodies as probes. Double-staining showed positivity for the CD19, CD20 and CD22 pan-B markers.

were also negative for CD45RO, a T cell marker also present on $\mathrm{B}$ cells nearing the plasma cell stage. Probing with the antiidiotypic antibodies failed to reveal circulating clonal plasma cells in the cases studied. However, alteration of the / ratio can be sometimes found in the peripheral blood PC of primary amyloidosis patients (12\% of 92 cases), suggesting that a minor population (median $0.5 \times 10^{6} / \mathrm{l}$ ) of clonal mature cells can occasionally be found. ${ }^{45}$ Cell-cycle analysis failed to detect any proliferative activity in the circulating amyloid elements, both in lymphocytes ${ }^{39}$ and plasma cells. ${ }^{45}$

The involvement of peripheral blood in $\mathrm{AL}$ amyloidosis has also been studied by tumor-specific PCR. Using very sensitive RT-PCR procedures with primers derived from the CDR sequence of the patient's amyloid light chain, clonal elements were found in virtually all patients at diagnosis (eight of 10$)^{46}$ and in apheretic peripheral blood stem cell preparations. ${ }^{46,47}$ Quantitative heavy chain $\mathrm{V}$ region-based PCR demonstrated that circulating tumor cells were rare $(0.01$ and $0.07 \%$ clonal cells in the two cases tested), a level of involvement similar to that found in MGUS. ${ }^{48}$ Of course, we have no information on the nature of the cells detected by these methods, but they seem to be clinically relevant because they persist after cyclophosphamide mobilization $^{46}$ and high-dose chemotherapy (unpublished observation). As in MM, circulating elements may be therefore chemoresistant and contribute to relapse. ${ }^{49,50}$

\section{The relationship between the various amyloid elements}

The amyloid clone diffuses systemically and comprises cells at various stages of late B cell differentiation. The morphology and immunophenotype of the circulating amyloid lymphoid cells are compatible with post-switched B lymphocytes. Similarly to multiple myeloma, ${ }^{51}$ a combination of IL-3 and IL-6 sustained the in vitro differentiation of these cells to PC that were very similar to those present in the bone marrow. ${ }^{39,52}$ Anti-idiotypic antibodies plus complement ${ }^{39}$ or immunotoxins to $C D 22,{ }^{52}$ a marker which is absent from PC, were capable of inhibiting the differentiation process, thus indicating that surface Ig/CD22 positive lymphocytes were responsible for the generation of the amyloid clonal PC in vitro. These results suggest a close relationship between the various amyloidogenic cell populations. In analogy to what is thought to occur during the normal immune humoral response, it is tempting to hypothesize that the circulating lymphoid elements are the precursors of the more differentiated bone marrow cell population: these cells should home to the bone marrow where they transform into PC, via the intermediate differentiation stages constituted by the lymphoid and lymphoplasmacytoid cells identified by the anti-idiotypic antibodies. A similar intraclonal differentiation process has been proposed for $M M,{ }^{53,54}$ and Waldenström's macroglobulinemia, ${ }^{55,56}$ and may therefore be common to monoclonal gammapathies. Figure 2 illustrates the proposed model of intraclonal differentiation for $\mathrm{AL}$ amyloidosis. However, the nature of the clonal stem cell, as well as the tumor proliferative compartment, are still elusive. Animal experimental models, such as those recently described for $M M,{ }^{57,58}$ will perhaps help to clarify these and other issues.

\section{Karyotypic and other genetic abnormalities in AL amyloidosis}

Classic cytogenetic analysis has been hampered by the scarcity of the bone marrow PC infiltration, the fact that these cells have low proliferative activity, and the possible detection of abnormalities in non-amyloid cells especially in heavily treated patients. In a cytogenetic study, Dewald et a/59 detected chromosome abnormalities in five of 13 patients with $\mathrm{AL}$ amyloidosis. The significance of these findings was, however, confounded by the subsequent development of acute non-lymphoblastic leukemia in three of the five patients and it was therefore uncertain whether the observed anomalies were present in the amyloid clone or in other myeloid cells. Only recently, by means of a technique coupling simultaneous fluorescent staining of the monotypic cytoplasmic immunoglobulin and interphase FISH, ${ }^{60}$ Fonseca et al ${ }^{61}$ tested bone marrows from 21 patients with $\mathrm{AL}$ amyloidosis for numerical chromosome anomalies, using centromere-specific probes for six chromosomes frequently reported as abnormal in MM. ${ }^{62}$ In all patients studied, nine of whom had received previous chemotherapy and one with associated MM, at least one

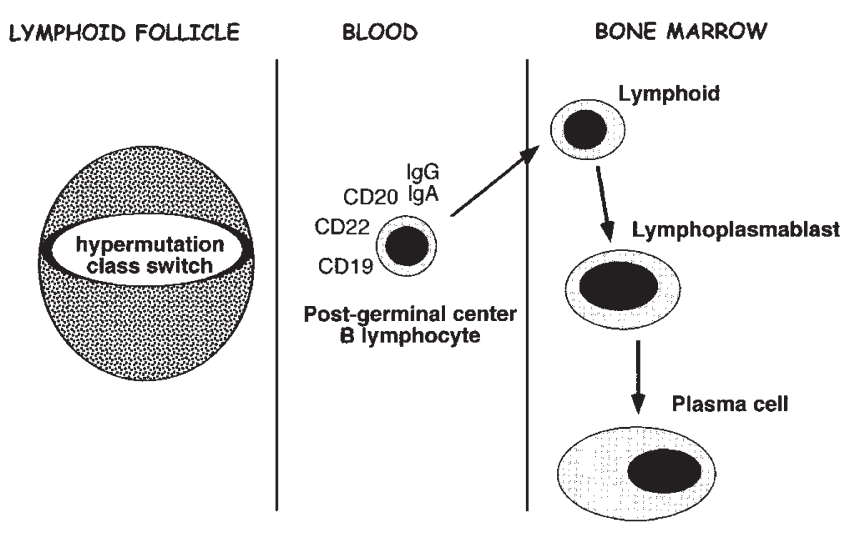

Figure 2 Hypothetical model of intraclonal differentiation in primary amyloidosis. The model is supported by in vitro data. The amyloid clone is constituted by post-germinal center elements: circulating mature post-switched B lymphocytes, bone marrow lymphoid, Iymphoplasmacytoid cells and plasma cells. B cell antigens expressed on circulating clonal cells are reported. Neither the clonal stem cell nor the tumor proliferative compartment has been identified. 
chromosomal abnormality was seen. In contrast, standard cytogenetic analysis was negative in 18 of the 20 cases $(90 \%)$ in which adequate metaphases could be obtained. Multiple numerical chromosomal abnormalities were detected by FISH. Loss of chromosome 18 was particularly common in $\mathrm{AL}$ (72\% of cases), a lesion not frequently detected in MM (6$11 \%$ of cases). ${ }^{62}$ Coexistence of trisomy for different chromosomes, as well as trisomy and monosomy for a given chromosome, were present in several samples, thus indicating the presence of cytogenetic subclones of amyloidogenic plasma cells in a given patient, as shown in MGUS. ${ }^{63}$ Alterations were similarly frequent in both treated and untreated patients and were therefore not therapy-related. No significant difference was observed in the prevalence of these abnormalities between AL and MGUS. Genomic instability is therefore common in AL. It will be of interest to test whether specific chromosome abnormalities have an impact on survival. In fact, although survival in $\mathrm{AL}$ is obviously related to the amyloid organ distribution, it is also related to therapy response, and biological variables are needed to identify those patients who are more likely to benefit from high-dose chemotherapy, ${ }^{64}$ which is a risky therapy. ${ }^{65}$

Chromosomal translocations involving the Ig heavy chain locus $14 q 32$ are common in MM and MGUS. ${ }^{66,67}$ Several partner chromosomes are involved, but translocation at 4 p16.3 is of particular interest because it leads to the apparent deregulation of two potential oncogenes, namely FGFR3 $3^{68,69}$ and MMSET. ${ }^{70}$ As consequence of translocation, IGH/MMSET fusion transcripts are generated, ${ }^{70}$ and these can be detected by a sensitive RT-PCR assay. ${ }^{71}$ We recently investigated bone marrow from $\mathrm{AL}$ patients for the presence of IGH/MMSET hybrid transcripts and found that $14 \%$ of cases were positive for $\mathrm{t}(4 ; 14)(\mathrm{p} 16.3 ; \mathrm{q} 32)$ translocation (Perfetti et al, manuscript in preparation). A frequency of approximately $20 \%$ was reported in MM..$^{71}$ The $t(4 ; 14)$ translocation appears therefore to be a recurrent genetic lesion in $\mathrm{AL}$, underlying the concept that $I G H$ translocations may represent early pathogenic events in plasma cell disorders. ${ }^{66}$

The persistence of neoplasias stands on a balance between proliferation and apoptosis of tumor cells. Many cytokines act on both these factors: they favor proliferation and prolong survival via inhibition of apoptosis. Apoptosis inhibition is therefore probably important, but this problem is only now being investigated. In a recent report, Witzig et $a^{2}$ developed a PC growth index that related both proliferation and apoptosis and found that there were higher proliferation and lower apoptosis rates in myeloma than in MGUS and $\mathrm{AL}$; it will be of interest to test whether apoptosis in amyloid PC is lower than in normal PC, which already live for long periods of time. ${ }^{34}$ Analysis of $\mathrm{BCl}-2$ and of other genes or proteins involved in apoptosis has not been performed in $\mathrm{AL}$ amyloidosis.

\section{Angiogenesis and HHV-8}

IL-6 is the major growth and survival (anti-apoptotic) factor in myeloma, ${ }^{73}$ and probably in $\mathrm{AL}$ as well. Indeed, sorted amyloid PC were reported to express IL-6 receptor $\mathrm{mRNA}^{74}$ and a combination of IL-6 and IL-3 drove clonal circulating lymphocytes to differentiate into PC in vitro. ${ }^{39}$ Amyloid PC did not express IL- $6 \mathrm{mRNA}^{74}$ thus other cells in the bone marrow could be the source of IL-6. Kaposi's sarcoma-associated herpesvirus (KSHV), a virus found within tumor tissue in Kaposi's sarcoma, Castleman's disease, and primary effusion lymphomas, bears several genes with functional homology to cellular genes, including IL- $6 .{ }^{75}$ An association between KSHV and bone marrow dendritic cells in $\mathrm{MM}$ was reported. ${ }^{76,77}$ Since viral IL-6 is able to sustain survival and proliferation of myeloma cells, albeit with much less efficiency than the human counterpart, ${ }^{78}$ these findings led to the attractive hypothesis that KSHV was involved in MM and related PC dyscrasias through infection of marrow dendritic cells and elaboration of viral IL-6 and other cytokine products. ${ }^{76}$ Very recently, ${ }^{79} \mathrm{KSHV}$ DNA sequences were found, albeit at a very low copy number, in PCR-amplified DNA from bone marrow biopsy samples and long-term bone marrow stromal cell cultures of a majority (85\%) of amyloid patients. On the other hand, antibodies to KSHV were observed only in a fraction of positive cases $(22 \%)$. Since the presence and role of KSHV in plasma cell dyscrasias remains controversial, ${ }^{80-81}$ the association between KSHV and amyloidosis warrants further investigation.

$\mathrm{KSHV}$ is associated with increased vascularization ${ }^{82}$ and neoangiogenesis is observed in marrow from patients with active myeloma. ${ }^{83}$ These observations suggested the use of the anti-angiogenetic drug thalidomide to overcome chemorefractory myeloma. Indeed, thalidomide proved to be effective in a portion of myeloma patients who had relapsed after conventional therapy and autologous transplantation. ${ }^{84}$ Thalidomide toxicity was mild and trials are ongoing in $\mathrm{AL}$ as well.

\section{The amyloid $\mathbf{V}$ region nucleotide sequences and clonal origins - germline gene usage and organ tropism}

Somatic mutations of Ig $\mathrm{V}$ regions are a marker of germinal center origin, and uniformity of such mutations indicates that the cell has stopped mutating and left the germinal center: ie it is a post-germinal center cell. Cells which are selected for the improved functionality of their Ig have a peculiar distribution of replacement and silent mutations in the $\mathrm{V}$ region: amino acid replacing substitutions are concentrated in the antigen contact regions, the CDR, whereas silent substitutions are found more frequently than expected in the framework regions, areas of structural relevance. ${ }^{85,86}$ The study of the $\mathrm{V}$ region nucleotide sequences of a $\mathrm{B}$ cell clone can therefore provide useful information on its ontogenesis, giving essential clues to the nature of the cell of origin and on the circumstances that accompanied its development. ${ }^{87,88}$

The elaboration of a novel inverse-PCR strategy ${ }^{89}$ that utilizes only primers for constant regions overcame difficulties in Ig $\mathrm{V}$ region sequencing. Amyloid $\mathrm{V}$ regions were found to be highly mutated compared to the closest germline genes in the databases or those isolated from the patients' $\mathrm{DNA} ;{ }^{90}$ the latter were found to be identical to the germline genes present in the general population, ie mutations were all acquired and there is no apparent predisposition to develop amyloidosis at the $\mathrm{VL}$ germline gene level. ${ }^{90}$ No amyloid light chain $\mathrm{V}$ region isolated so far is in germline configuration, but the extent of somatic changes appears to vary widely. ${ }^{90}$ It is unclear whether deviation from the germline is greater in amyloid $\mathrm{VL}$ regions than in non-amyloidogenic ones. Mutations were not associated with intraclonal diversification, every clonal cell expressed VL regions sharing identical somatic mutations, ie the clone was no longer under the influence of the hypermutation process in the germinal center. ${ }^{90}$ These findings provided evidence that the earlier amyloid cell could not possibly be a germinal or pre-germinal center cell, in agreement with the cells types identified in the immunophenotypic and functional studies employing the anti-idiotypic monoclonal antibodies (Figure 2). ${ }^{39}$ 
An important point was to test whether amyloidogenic light chains undergo the same antigen-mediated affinity selection process seen in non-pathological light chains. ${ }^{85}$ Analysis of the nature and distribution of somatic mutations in amyloid $\mathrm{V}$ regions revealed significant evidence of antigen selection in a substantial proportion of cases (eight of 14). ${ }^{90}$ These results indicate that amyloid clones developed from post-germinal center B cells selected for improved antigen binding properties, and that pathogenic light chains did not appear to result from a quality control failure. At some point in its history, the amyloid light chain was part of an antibody capable of improved functional binding to a $\mathrm{T}$ cell-dependent antigen.

Amyloid $\mathrm{V}$ region protein sequencing ${ }^{91}$ and ELISA typing with monoclonal antibodies specific for the various VL germline gene families $^{92}$ demonstrated a strong association between the $\mathrm{V}$ VI family and amyloidosis: with rare exceptions, VI monoclonal light chains isolated so far are found in patients with AL. This rare subgroup of light chains seems to constitute approximately $5 \%$ of the circulating light chains, ${ }^{93}$ but apparently up to $40 \%$ of the amyloidogenic ones. ${ }^{92}$ A very recent genetic analysis reported, in a selected population undergoing high-dose chemotherapy, an association between the usage of the VI family and predominant or exclusive amyloid involvement of kidney (14/14 cases). ${ }^{94}$ This work raised the possibility that the diverse organ tropism that influences the clinical picture of amyloidosis may be ruled by gene usage. We recently undertook the first analysis of $\mathrm{V}$ germline gene usage in a general population of $\mathrm{AL}$ patients $^{95}$ and found that eight of the 11 VI patients $(73 \%)$ had major or exclusive kidney involvement (Perfetti et al, manuscript in preparation). It will be of interest to test whether gene usage may influence prognosis and, particularly, amyloid heart disease.

\section{Therapeutic implications}

Useful information can be drawn from the reported studies. Despite the fact that amyloid light chains are synthesized only by $\mathrm{PC}$ resident in the bone marrow, earlier clonal cells are also involved; circulating amyloid elements are present at diagnosis and in apheretic stem cell preparations, and reinfusion of clonal cells might contribute to recurrence after highdose chemotherapy. ${ }^{16}$ Ex vivo purging strategies, such as positive selection for $\mathrm{CD}_{3} 4^{+}$cells ${ }^{47}$ and/or negative selection for $\mathrm{CD} 19^{+} / \mathrm{CD} 20^{+}$lymphocytes in stem cell preparations, may be employed. The very low proliferative activity of the amyloid elements suggests the need for strategies active on non-cycling cells, such as immunotherapy. In this respect, the cytotoxicity of the bispecific anti-CD22/anti-saporin antibodies against myeloma and amyloid circulating elements ${ }^{52}$ convinced us to initiate a pilot study in patients with chemoresistant $A L$, but early development of strong human anti-mouse and anti-toxin antibody responses impeded full exploitation of the therapeutic potential of this immunotoxin (unpublished observations). Analogous immune responses were observed in three of the five myeloma patients treated with murine antiCD19-blocked ricin. ${ }^{96}$ The use of the anti-CD20 chimeric human-mouse antibody, Rituxan, may overcome these problems, though activity appears to be limited to the small fraction of myeloma patients with $\mathrm{CD} 20^{+} \mathrm{PC} .{ }^{97}$ The immune system in monoclonal gammapathies may therefore be less altered than expected, and this offers a rationale for the development of anti-tumor vaccines. A trial of dendritic cell-based idiotype vaccination in $\mathrm{AL}$ has been started at the Mayo Clinic and one of the five patients has had a documented hematologic complete response. ${ }^{98}$ In this same patient, specific T cell proliferative responses to idiotype were detectable. No toxicity was seen in any of the cases. This strategy may be particularly useful when tolerance is expected to be reduced as in the context of minimal residual disease.

In conclusion, the studies reviewed in this paper provided clues to a better understanding of the pathobiology of the amyloid clone. Much remains to be learned, but future advances in $\mathrm{AL}$ therapy will probably stem from progress in this field.

\section{Acknowledgements}

This work was supported by AIRC, European Biomed 2 (Programme BMH4-CT 98-3689), Progetto di Ateneo, MURST 1999 (prot. 9906038391-007), Fondazione Ferrata-Storti, and IRCCS Policlinico S Matteo.

\section{References}

1 Glenner GG. Amyloid deposits and amyloidosis: the beta-fibrilloses. N Engl J Med 1980; 302: 1283-1292, 1333-1343.

2 Ionescu-Zanetti C, Khurana R, Gillespie JR, Petrick JS, Trabachino LC, Minert LJ, Carter SA, Fink AL. Monitoring the assembly of the Ig light-chain amyloid fibrils by atomic force microscopy. Proc Natl Acad Sci USA 1999; 96: 13175-13179.

3 Glenner GG, Eanes ED, Page DL. The relation of the properties of congo red stained amyloid fibrils to the beta-conformation. J Histochem Cytochem 1972; 20: 821-826.

4 Stone MJ. Amyloidosis: a final common pathway for protein deposition in tissues. Blood 1990; 75: 531-545.

5 Falk RH, Comenzo RL, Skinner M. The systemic amyloidoses. N Engl J Med 1997; 337: 898-909.

6 Gillmore JD, Hawkins PN, Pepys MB. Amyloidosis: a review of recent diagnostic and therapeutic developments. $\mathrm{Br} / \mathrm{Haematol}$ 1997; 99: 245-256.

7 Westermark P, Araki S, Benson MD, Cohen AS, Frangione B, Masters CL, Saraiva MJ, Sipe JD. Nomenclature of amyloid fibril proteins. Report from the meeting of the International Nomenclature Committee on Amyloidosis, 8-9 August 1998. Amyloid Int J Exp Clin Invest 1999; 6: 63-66.

8 Merlini G. Treatment of primary amyloidosis. Semin Hematol 1995: 32: 60-79.

9 Perfetti V, Bellotti V, Maggi A, Arbustini E, De Benedetti F, Paulli M, Marinone MG, Merlini G. Reversal of nephrotic syndrome due to reactive amyloidosis (AA-type) after excision of localized Castleman's disease. Am J Hematol 1994; 46: 189-193.

10 Hawkins PN. Studies with radiolabelled serum amyloid P component provide evidence for turnover and regression of amyloid deposits in vivo. Clin Sci 1994; 87: 289-295.

11 Hawkins PN, Vigushin DM, Richardson S, Seymour A, Pepys MB. Evaluation of 100 cases of systemic AL amyloidosis by serum amyloid P component (SAP). In: Kisilevskiy R, Benson MD, Frangione B, Gauldie J, Muckle TJ, Young ID (eds). Amyloid and Amyloidosis 1993. Parthenon Publishing: New York, 1994, pp 209-211.

12 Merlini G. AL amyloidosis. In: Kyle RA, Gertz MA (eds). Amyloid and Amyloidosis 1998. Parthenon Publishing: New York, 1999, pp 88-95.

13 Lansbury PT. Evolution of amyloid: what normal protein folding may tell us about fibrillogenesis and disease. Proc Natl Acad Sci USA 1999; 96: 3342-3345.

14 Gertz MA, Lacy MQ, Dispenzieri A. Amyloidosis. Hematol Oncol Clin North Am 1999; 13: 1211-1233.

15 Kyle RA, Gertz MA. Primary systemic amyloidosis: clinical and laboratory features in 474 cases. Semin Hematol 1995; 32: 45-59.

16 Comenzo RL, Vosburgh E, Falk RH, Sanchorawala V, Reisinger J, Dubrey S, Dember LM, Berk JL, Akpek G, LaValley M, Arkin CO, Wright DG, Skinner M. Dose-intensive melphalan with blood stem-cell support for the treatment of AL (amyloid light-chain) 
amyloidosis: survival and responses in 25 patients. Blood 1998; 91: 3662-3670.

17 Comenzo RL, Sanchorawala V, Fisher C, Akpek G, Farhat M, Cerda S, Berk JL, Dember LM, Falk R, Finn K, Skinner M, Vosburg $\mathrm{E}$. Intermediate-dose intravenous melphalan and blood stem cells mobilized with sequential GM + G-CSF or G-CSF alone to treat AL (amyloid light chain) amyloidosis. Br J Haematol 1999; 104: 553-559.

18 Moreau P, Leblond V, Bourquelot P, Facon T, Huynh A, Caillot D, Hermine O, Attal M, Hamidou M, Nedellec G, Ferrant A, Audhuy B, Bataille R, Milpied N, Harousseau JL. Prognostic factors for survival and response after high-dose therapy and autologous stem cell transplantation in systemic $\mathrm{AL}$ amyloidosis: a report on 21 patients. Br J Haematol 1998; 101: 766-769.

19 Kyle RA. High-dose therapy in multiple myeloma and primary amyloidosis: an overview. Semin Oncol 1999; 26: 74-83.

20 Gianni L, Bellotti V, Gianni MA, Merlini G. New drug therapy of amyloidoses: resorption of AL-type deposits with 4 -iodo-4 deoxydoxorubicin. Blood 1995; 86: 855-861.

21 Kyle RA, Greipp PR. Amyloidosis (AL): clinical and laboratory features in 229 cases. Mayo Clin Proc 1983; 58: 665-683.

22 Merlini G, Anesi E, Banfi G, Baraldi A, Bergesio, Bertani T, BucaIossi A, Cavallero G, Conte N, De Luca M, Di Girolamo M, Fabris A, Faedda R, Fregoni V, Frosi A, Furci L, Girelli D, Grassi C, lannacone S, Imbasciati E, Loni C, Manganaro M, Manno C, Marcenò R, Marenzi V, Marinone MG, Marzani F, Melis P, Miliani A, Montanaro M, Musto P, Pannacciulli I, Pecchini F, Perfetti V, Pintus F, Pozzi C, Resegotti L, Schena FP, Uziel L, Visconti G, Ascari E. $\mathrm{AL}$ amyloidosis: update of a multicenter study. Haematologica 1996; 81: 52 (Abstr.).

23 Kyle RA, Gertz MA, Greipp PR, Witzig TE, Lust JA, Lacy MQ, Therneau TM. Long-term survival (10 years or more) in 30 patients with primary amyloidosis. Blood 1999; 93: 1062-1066.

24 Solomon A, Weiss DT. Protein and host factors implicated in the pathogenesis of light chain amyloidosis (AL amyloidosis). Amyloid Int J Exp Clin Invest 1995; 2: 269-279.

25 Ferri G, Stoppini M, ladarola P, Bellotti V, Merlini G. Structural characterization of kappa II Inc, a new amyloid immunoglobulin. Biochim Biophys Acta 1989; 995: 103-108.

26 Hurle MR, Helms LR, Li L, Wetzel R. A role for destabilizing amino acid replacements in light-chain amyloidosis. Proc Natl Acad Sci USA 1994; 91: 5446-5450.

27 Raffen R, Dieckman LJ, Szpunar M, Wunschl C, Pokkuluri PR, Dave P, Wilkins Steven P, Cai X, Schiffer M, Stevens FJ. Physicochemical consequences of amino acid variations that contribute to fibril formation by immunoglobulin light chains. Protein Sci $1999 ; 8$ : 509-517.

28 Wetzel R. Domain stability in immunoglobulin light chain deposition disorders. In: Wetzel R (ed). Protein Misassembly. Academic Press: New York, 1997, pp 183-242.

29 Benner R, Hijmans W, Haaijman JJ. The bone marrow: the major source of serum immunoglobulins, but still a neglected site of antibody formation. Clin Exp Immunol 1981; 46: 1-8.

30 Paramithiotis E, Cooper MD. Memory B lymphocytes migrate to bone marrow in humans. Proc Natl Acad Sci USA 1997; 94: 208-212

31 Dilosa RM, Maeda K, Masuda A, Szakal AK, Tew JG. Germinal center B cells and antibody production in the bone marrow. J Immunol 1991; 146: 4071-4077.

32 Slifka MK, Matloubian M, Ahmed R. Bone marrow is a major site of long-term antibody production after acute viral infection. J Virol 1995; 69: 1895-1902.

33 MacLennan IC, Liu Y-J, Oldfield S, Zhang J, Lane PJ. The evolution of B-cell clones. Curr Top Microbiol Immunol 1990; 159: 37-63.

34 Manz RA, Thiel A, Radbruch A. Lifetime of plasma cells in the bone marrow. Nature 1997; 388: 133-134.

35 Hamidi Asl K, Liepnieks JJ, Bihrle R, Benson MD. Local synthesis of amyloid fibril precursor in $\mathrm{AL}$ amyloidosis of the urinary tract. Amyloid Int J Exp Clin Invest 1998; 5: 49-54.

36 Hamidi Asl K, Liepnieks JJ, Nakamura M, Benson MD. Organspecific (localized) synthesis of Ig light chain amyloid. J Immunol 1999; 162: 5556-5560.

37 Laeng RH, Altermatt HJ, Scheithauer BW, Zimmermann DR. Amyloidomas of the nervous system. A monoclonal B cell disorder with monotypic amyloid light chain lambda amyloid production. Cancer 1998; 82: 362-374.

38 Bellotti V, Stoppini M, Perfetti V, Zorzoli I, Marinone G, Invernizzi R, Zambelli LM, Arbustini E, Grasso M, Ferri G, Ascari E, Merlini G. Use of anti-idiotypic monoclonal antibody in studying amyloidogenic light chains in cells, urine and fibrils: pathophysiology and clinical implications. Scand J Immunol 1992; 36: 607-615.

39 Perfetti V, Bellotti V, Garini P, Zorzoli I, Rovati B, Marinone MG, Ippoliti G, Merlini G. AL amyloidosis: characterization of amyloidogenic cells by anti-idiotypic antibodies. Lab Invest 1994; 71: 853-861.

40 Gertz MA, Kyle RA, Greipp PR. The plasma cell labeling index: a valuable tool in primary systemic amyloidosis. Blood 1989; 74 : 1108-1111.

41 Gertz MA, Greipp PR, Kyle RA. Classification of amyloidosis by detection of clonal excess of plasma cells in the bone marrow. J Lab Clin Med 1991; 118: 33-39.

42 Perfetti V, Garini P, Colli Vignarelli M, Marinone MG, Zorzoli I, Merlini G. Diagnostic approach to and follow-up of difficult cases of AL amyloidosis. Haematologica 1995; 80: 409-415.

43 Perfetti V, Colli Vignarelli M, Anesi E, Garini P, Quaglini S, Ascari E, Merlini G. The degrees of plasma cell clonality and marrow infiltration adversely influence the prognosis of $\mathrm{AL}$ amyloidosis patients. Haematologica 1999; 84: 218-221.

44 Merlini G, Anesi G, Banfi G, Baraldi A, Bergesio F, Bertani T, Cavallero G, Conte N, Cossu M, De Luca M, Di Girolamo M, Epis R, Faedda R, Fregoni V, Frigerio G, Frosi A, Furci L, Garini P, Girelli D, Grassi C, lannacone S, Imbasciati E, Loni C, Manganaro M, Manno C, Marcenò R, Marenzi V, Marcatti M, Marinone G, Marzani F, Melis P, Milaini A, Montanaro M, Musto P, Palladini G, Parisio E, Pecchini F, Perfetti V, Pintus F, Pozzi C, Quaglini S, Quarenghi M, Schena FP, Tocci A, Uziel L, Ascari E. AL amyloidosis: clinical and therapeutic aspects. In: Kyle RA, Gertz MA (eds). Amyloid and Amyloidosis 1998. Parthenon Publishing: New York, 1999, pp 142-144.

45 McElroy EA, Witzig TE, Gertz MA, Greipp PR, Kyle RA. Detection of monoclonal plasma cells in the peripheral blood of patients with primary amyloidosis. Br J Haematol 1998; 100: 326-327.

46 Perfetti V, Ubbiali P, Magni M, Colli Vignarelli M, Casarini S, Matteucci P, Gianni AM, Merlini G. Cells with clonal light chains are present in peripheral blood at diagnosis and in apheretic stem cell harvests of primary amyloidosis. Bone Marrow Transplant 1999; 23: 323-327.

47 Comenzo RL, Michelle D, LeBlanc M, Wally J, Zhang Y, Kica G, Karandish S, Arkin CF, Wright DG, Skinner M, McMannis J. Mobilized $\mathrm{CD}_{3} 4^{+}$cells selected as autografts in patients with primary light-chain amyloidosis: rationale and application. Transfusion 1998; 38: 60-69.

48 Billadeau D, Van Ness B, Kimlinger T, Kyle RA, Therneau TM, Greipp PR, Witzig TE. Clonal circulating cells are common in plasma cell proliferative disorders: a comparison of monoclonal gammopathy of undetermined significance, smoldering multiple myeloma, and active myeloma. Blood 1996; 88: 289-296.

49 Bergsagel PL, Smith AM, Szczepek A, Mant MJ, Belch AR, Pilarski LM. In multiple myeloma, clonotypic B lymphocytes are detectable among $\mathrm{CD}_{19}{ }^{+}$peripheral blood cells expressing CD38, CD56, and monotypic immunoglobulin light chain. Blood 1995; 85: 436-447.

50 Pilarski LM, Belch AJ. Circulating monoclonal B cells expressing $\mathrm{P}$ glycoprotein may be a reservoir of multidrug-resistant disease in multiple myeloma. Blood 1994; 83: 724-736.

51 Bergui L, Schena M, Gaidano G, Riva M, Caligaris-Cappio F. Interleukin-3 and interleukin-6 synergistically promote the proliferation and differentiation of malignant plasma cell precursors in multiple myeloma. J Exp Med 1989; 170: 613-618.

52 Perfetti V, Colli Vignarelli M, Bellotti V, Glennie MJ, Zorzoli I, Ubbiali P, Obici L, Massa M, Ippoliti G, Ascari E, Merlini G. Membrane CD22 defines circulating myeloma-related cells as mature or later B cells. Lab Invest 1997; 77: 333-344.

53 Pilarski LM, Jensen GS. Monoclonal circulating B cells in multiple myeloma. A continuously differentiating, possibly invasive, population as defined by expression of CD45 isoforms and adhesion molecules. Hematol Oncol Clin North Am 1992; 6: 297-322.

54 Pilarski LM, Masellis-Smith A, Szczepek A, Mant MJ, Belch AR. Circulating clonotypic B cells in the biology of multiple myeloma: 
speculations on the origin of myeloma. Leuk Lymphoma 1996 22: 375-383.

55 Andrews EJ, Mant MJ, Vergidis R, Ledbetter JA, Pilarski LM. Transitions in CD45 isoform expression indicate continuous differentiation of a monoclonal CD5 ${ }^{+} \mathrm{CD} 11 \mathrm{~b}^{+} \mathrm{B}$ lineage in Waldenström's macroglobulinemia. Am J Hematol 1991; 37: 20-30.

56 Kucharska-Pulczynska M, Ellegaard J, Hokland P. Analysis of leukocyte differentiation antigens in blood and bone marrow from patients with Waldenström's macroglobulinemia. Br J Haematol 1987; 65: 395-399.

57 Yaccoby S, Barlogie B, Epstein J. Primary myeloma cells growing in SCID-hu mice: a model for studying the biology and treatment of myeloma and its manifestations. Blood 1998; 92: 2908-2913.

58 Pilarski LM, Hipperson G, Seeberger K, Pruski E, Coupland RW, Belch AR. Myeloma progenitors in the blood of patients with aggressive or minimal disease: engraftment and self-renewal of primary human myeloma in the bone marrow of NOD SCID mice. Blood 2000; 95: 1056-1065.

59 Dewald GW, Kyle RA, Hicks GA, Greipp PR. The clinical significance of cytogenetic studies in 100 patients with multiple myeloma, plasma cell leukemia, or amyloidosis. Blood 1985; 66: 380-390.

60 Ahmann GJ, Jalal SM, Juneau AL, Christensen ER, Hanson CA, Dewald GW, Greipp PR. A novel three-color, clone-specific fluorescence in situ hybridization procedure for monoclonal gammopathies. Cancer Genet Cytogenet 1998; 101: 7-11.

61 Fonseca R, Ahmann GJ, Jalal SM, Dewald GW, Larson DR, Therneau TM, Gertz MA, Kyle RA. Chromosomal abnormalities in systemic amyloidosis. Br J Haematol 1998; 103: 704-710.

62 Drach J, Schuster J, Nowotny H, Angerler J, Rosenthal F, Fiegl M, Rothermundt C, Gsur A, Jager U, Heinz R, Huber H. Multiple myeloma: high incidence of chromosomal aneuploidy as detected by interphase fluorescence in situ hybridization. Cancer Res 1995 ; 55: 3854-3859.

63 Zandecki M, Lai J-L, Geneviève F, Bernardi F, Volle-Rèmy H, Blanchet O, Francoise M, Cosson A, Bauters F, Facon T. Several cytogenetic subclones may be identified within plasma cells from patients with monoclonal gammopathy of undetermined significance, both at diagnosis and during the indolent course of this condition. Blood 1997; 90: 3682-3690.

64 Tricot G, Sawyer JR, Jagannath S, Desikan KR, Siegel D, Naucke S, Mattox S, Bracy D, Munshi N, Barlogie B. Unique role of cytogenetics in the prognosis of patients with myeloma receiving highdose therapy and autotransplants. J Clin Oncol 1997; 15: 26592666 .

65 Moreau P. Autologous stem cell transplantation for AL amyloidosis: a standard therapy? Leukemia 1999; 13: 1929-1931.

66 Hallek M, Bergsagel PL, Anderson KC. Multiple myeloma: increasing evidence for a multistep transformation process. Blood 1998; 91: 3-21.

67 Avet-Loiseau H, Li JY, Facon T, Morineau N, Maloisel F, Rapp MJ, Talmant P, Trimoreau F, Jaccard A, Harousseau JL, Bataille R. High incidence of translocations $\mathrm{t}(11 ; 14)(\mathrm{q} 13 ; \mathrm{q} 32)$ and $\mathrm{t}(4 ; 14)(\mathrm{p} 16 ; \mathrm{q} 32)$ in patients with plasma cell malignancies. Cancer Res 1998; 58 : 5640-5645.

68 Richelda R, Ronchetti D, Baldini L, Cro L, Viggiano L, Marzella R, Rocchi M, Otsuki T, Lombardi L, Maiolo T, Neri A. A novel chromosomal translocation $\mathrm{t}(4 ; 14)(\mathrm{p} 16.3 ; \mathrm{q} 32)$ in multiple myeloma involves the fibroblast growth-factor receptor 3 gene. Blood 1997; 90: 4062-4070.

69 Chesi M, Nardini E, Brents LA, Schroch E, Ried T, Kuehl WM Bergsagel PL. Frequent translocation $\mathrm{t}(4 ; 14)(\mathrm{p} 16.3 ; \mathrm{q} 32.3)$ in multiple myeloma is associated with increased expression and activating mutations of fibroblast growth factor receptor 3. Nat Genet 1997; 16: 260-264.

70 Chesi M, Nardini E, Lim RSC, Smith KD, Kuehl MW, Bergsagel $\mathrm{PL}$, Ried T. The $\mathrm{t}(4 ; 14)$ translocation in myeloma dysregulates both FGFR3 and a novel gene, MMSET, resulting in IgH/MMSET hybrid transcripts. Blood 1998; 92: 3025-3034.

71 Malgeri U, Baldini L, Perfetti V, Fabris S, Colli Vignarelli M, Colombo G, Lotti V, Compasso S, Bogni S, Lombardi L, Maiolo AT, Neri A. Detection of $\mathrm{t}(4 ; 14)(\mathrm{p} 16.3 ; \mathrm{q} 32)$ chromosomal translocation in multiple myeloma by reverse transcription-polymerase chain reaction analysis of $I G H-M M S E T$ fusion transcripts. Cancer Res 2000; 60: 4058-4061.
72 Witzig TE, Timm M, Larson D, Therneau T, Greipp PR. Measurement of apoptosis and proliferation of bone marrow plasma cells in patients with plasma cell proliferative disorders. Br J Haematol 1999; 104: 131-137.

73 Klein B, Zhang X-G, Lu Z-Y, Bataille R. Interleukin-6 in human multiple myeloma. Blood 1995; 85: 863-872.

74 Donovan KA, Lacy MQ, Kline MP, Ahmann GJ, Heimbach JK, Kyle RA, Lust JA. Contrast in cytokine expression between patients with monoclonal gammopathy of undetermined significance or multiple myeloma. Leukemia 1988; 12: 593-600.

75 Moore PS, Boshoff C, Weiss RA, Chang Y. Molecular mimicry of human cytokine and cytokine response pathway genes by KSHV. Science 1996; 274: 1739-1744.

76 Rettig MB, Ma HJ, Vescio RA, Pold M, Schiller G, Belson D, Savage A, Nishikubo C, Wu C, Fraser J, Said JW, Berenson JR. Kaposi's sarcoma-associated herpesvirus infection of bone marrow dendritic cells from multiple myeloma patients. Science 1997; 276: 1851-1854.

77 Said JW, Rettig MR, Heppner K, Vescio RA, Schiller G, Ma HJ, Belson D, Savage A, Shintaku P, Koeffler HP, Asou H, Pinkus G, Pinkus J, Schrage M, Green E, Berenson JR. Localization of Kaposi's sarcoma-associated herpesvirus in bone marrow biopsy samples from patients with multiple myeloma. Blood 1997; 90: 4278-4282.

78 Burger R, Neipel F, Fleckenstein B, Savino R, Ciliberto G, Kalden JR, Gramatzki M. Human herpesvirus type 8 interleukin-6 homologue is functionally active on human myeloma cells. Blood 1998; 91: 1858-1863.

79 Raje N, Kica G, Chauhan D, Zhang Y, Teoh G, Treon SP, Hideshima T, Deng JH, Gao SJ, Alsina M, Wally J, Davies FE, Tai YT, Pinkus GS, Pinkus JL, Skinner M, Comenzo RL, Anderson KC. Kaposi's sarcoma-associated herpesvirus gene sequences are detectable at low copy number in primary amyloidosis. Amyloid Int J Exp Clin Invest 2000; 7: 126-132.

80 Berenson JR, Vescio RA. HHV-8 is present in multiple myeloma patients. Blood 1999; 93: 3157-3159.

81 Tarte K, Chang Y, Klein B. Kaposi's sarcoma-associated herpesvirus and multiple myeloma: lack of criteria for causality. Blood 1999; 93: 3159-3163.

82 Bais C, Santomasso B, Coso O, Arvanitakis L, Geras Raaka E, Gutkind JS, Asch AS, Cesarman E, Mesri EA. G-protein-coupled receptor of Kaposi's sarcoma-associated herpesvirus is a viral oncogene and angiogenesis activator. Nature 1998; 391: 86-89.

83 Vacca A, Ribatti D, Presta M, Minischetti M, lurlaro M, Ria R, Albini A, Bussolino F, Dammacco F. Bone marrow neovascularization, plasma cell angiogenic potential, and matrix metalloproteinase-2 secretion parallel progression of human multiple myeloma. Blood 1999; 93: 3064-3073.

84 Singhal S, Mehta J, Desikan R, Ayers D, Roberson P, Eddlemon P, Munshi N, Anaissie E, Wilson C, Dhodapkar M, Zeddis J, Barlogie $B$. Antitumor activity of thalidomide in refractory multiple myeloma. N Engl J Med 1999; 341: 1565-1571.

85 Shlomchik MJ, Aucoin AH, Pisetsky DS, Weigert MG. Structure and function of anti-DNA autoantibodies derived from a single autoimmune mouse. Proc Natl Acad Sci USA 1987; 84: 91509154.

86 Chang B, Casali P. The CDR1 sequences of a major proportion of human germline Ig $\mathrm{VH}$ genes are inherently susceptible to amino acid replacement. Immunol Today 1994; 15: 367-373.

87 Stewart AK, Schwartz RS. Immunoglobulin V regions and the B cell. Blood 1994; 83: 1717-1730.

88 Küppers R, Klein U, Hansmann M-L, Rajewsky K. Cellular origin of human B-cell lymphomas. N Engl J Med 1999; 341: 15201529.

89 Perfetti V, Sassano M, Ubbiali P, Colli Vignarelli M, Arbustini E, Corti A, Merlini G. Inverse polymerase chain reaction for cloning complete human immunoglobulin variable regions and leaders conserving the original sequence. Anal Biochem 1996; 239: 107-109.

90 Perfetti V, Ubbiali P, Colli Vignarelli M, Diegoli M, Fasani R, Stoppini M, Lisa A, Mangione P, Obici L, Arbustini E, Merlini G. Evidence that amyloidogenic light chains undergo antigen-driven selection. Blood 1998; 91: 2948-2954

91 Solomon A, Frangione B, Franklin EC. Bence-Jones proteins and light chains of immunoglobulins. Preferential association of the 
VlambdaVI subgroup of human light chains with amyloidosis $\mathrm{AL}$ (lambda). J Clin Invest 1982; 70: 453-460.

92 Ozaki S, Abe M, Wolfenbarger D, Weiss DT, Solomon A. Preferential expression of human lambda-light-chain variable-region subgroups in multiple myeloma, AL amyloidosis, and Waldenström's macroglobulinemia. Clin Immunol Immunopathol 1994; 71: 183-189.

93 Abe M, Ozaki S, Wolfenbarger D, deBram-Hart M, Weiss DT, Solomon A. Variable-region subgroup distribution among lambdatype immunoglobulins in normal human serum. J Clin Lab Anal 1984; 8: 4-9.

94 Comenzo RL, Wally J, Kica G, Murray J, Ericsson T, Skinner M, Zhang Y. Clonal immunoglobulin light chain variable region germline gene use in AL amyloidosis: association with dominant amyloid-related organ involvement and survival after stem cell transplantation. Br J Haematol 1999; 106: 744-751.

95 Perfetti V, Colli Vignarelli M, Casarini S, Palladini G, Ascari E,
Merlini G. V lambda family and germline gene usage in AL amyloidosis. Blood 1999; 94 (Suppl. 1): 544a-545a (Abstr. 2434).

96 Grossbard ML, Fidias P, Kinsella J, O'Toole J, Lambert JM, Blatter WA, Esseltine D, Braman G, Nadler LM, Anderson KC. Anti-B4blocked ricin: a phase II trial of 7 day continuous infusion in patients with multiple myeloma. Br J Hematol 1998; 102: 509515.

97 Treon SP, Shima Y, Preffer FI, Doss DS, Ellman L, Schlossman RL, Grossbard ML, Belch AR, Pilarski LM, Anderson KC. Treatment of plasma cell dyscrasias by antibody-mediated immunotherapy. Semin Oncol 1999; 26: 97-106.

98 Lacy MQ, Wettstein P, Gastineau DA, Greipp PR, Fonseca R, Dispenzieri A, Lust J, Witzig T, Rajkumar SV, Valone F, Kyle RA, Gertz MA. Dendritic cell-based idiotype vaccination for primary systemic amyloidosis. Blood 1999; 94 (Suppl. 1): 122a (Abstr. 535) 